\title{
EMPOWERING TEACHER OF RELIGIOUS EDUCATION IN MULTICULTURAL SOCIETY
}

\author{
MUSLIH ${ }^{1}$ \\ Universitas Islam Negeri Walisongo Semarang
}

\section{Abstract}

This paper revealed the result of research regarding the position of teacher, focusing on the importance of empowering teacher of religious education in multicultural society, such as Indonesia. Methodologically, it is a qualitative undertaking of literary research. Employing the technique of content analysis this study scrutinized features of multicultural society, exemplary profile of teacher of religious education, as well as how to empower this kind of teacher in order to fit in with diverse society. The findings of this research are, multicultural society can be understood as a society which consists of several cultural communities with their overlapping but distinct conception of the world, system of meaning, values, forms of social organizations, histories, customs and practices. The idealized profile of teacher of religious education is a type of teacher who meets the certain qualifications prescribed by Islamic teachings and guided by the law and regulation in Indonesia, in particular. Teacher of religious education have a very important role in preparing students to be good citizens in a multicultural society. Therefore the teacher of religious education must have awareness that he or she is part of a multicultural society. The teacher should be empowered to instill in his or her students an inclusive religious understanding to make them tolerant and respectful of other people of different cultures and religions, which is essential in order to strengthen harmony and national unity.

Corresponding author; email: ${ }^{1}$ muslih@walisongo.ac.id

ISSN 0852-7172 (p) 2461-064X (e)

(C) 2017 Walisongo: Jurnal Penelitian Sosial Keagamaan

http://journal.walisongo.ac.id/index.php/walisongo 


\section{MUSLIH}

Makalah ini mengungkapkan hasil penelitian mengenai posisi guru, berfokus pada pentingnya memberdayakan guru pendidikan agama dalam masyarakat multikultural, seperti Indonesia. Secara metodologis, ini adalah sebuah upaya penelitian literatur (kualitatif). Dengan menggunakan teknik content analysis penelitian ini menganalisa features masyarakat multikultural, profil ideal guru pendidikan agama, serta bagaimana memberdayakan guru semacam ini agar sesuai dengan kondisi masyarakat yang beraneka ragam. Temuan penelitian ini adalah, masyarakat multikultural dapat dipahami sebagai masyarakat yang terdiri dari beberapa komunitas budaya dengan konsepsi yang tumpang tindih tapi berbeda tentang dunia, sistem makna, nilai, bentuk organisasi sosial, sejarah, adat istiadat dan praktek. Profil ideal guru pendidikan agama adalah jenis guru yang memenuhi kualifkasi tertentu yang ditentukan oleh ajaran Islam dan dipandu oleh hukum dan peraturan di Indonesia, khususnya. Guru pendidikan agama memiliki peran yang sangat penting dalam mempersiapkan murid-murid untuk menjadi warga negara yang baik di tengah masyarakat multikulural. Oleh karena itu guru pendidikan agama harus memiliki kesadaran bahwa ia adalah bagian dari masyarakat multikultural. Guru tersebut harus diberdayakan untuk menanamkan dalam diri muridnya pemahaman keagamaan yang inklusif untuk membuat mereka toleran dan hormat pada orang lain yang berbeda kultur dan agama, ini penting dilakukan agar dapat mempekuat harmoni dan kesatuan nasional.

Keywords: education; multicultural society; religious education; teacher; tolerance.

\section{Introduction}

Indonesia is one of the biggest multicultural countries in the world. Indonesia's population adheres to religions and beliefs as diverse as Islam, Christianity, Catholicism, Hinduism, Buddhism, Confucianism and various cults. All is put within a single clump of the Republic of Indonesia (NKRI). This diversity can be considered as the potency and uniqueness owned by Indonesia as a great nation. 
However, the diversity and uniqueness are so far had no place in the process of nation-building, they are often recognized as the cause of the problems facing this nation today such as corruption, collusion, nepotism, political conflict, poverty, violence, separatism and so on. Richness and diversity of religion, ethnicity, and culture in Indonesia are like a double-edged knife. On the one hand, this is a wealth of treasures that should be maintained and give the feel and dynamics for the nation, but on the other hand, it can also be a starting point of dispute, vertical and horizontal conflicts (Baidhawy 2005, 21).

In fact, diversity in a community can provide positive energy when it is used as capital to build a nation together in a relationship of mutual giving and receiving, but otherwise if diversity is framed by the interpretation which is based on a symbol that binds or pressing where prejudice, suspicion, bias, and reduction of the outside group exists then it will just be a time-bomb which can destroy structure and pillar of nationality (Hilmy 2003, 333).

History has told us that negative attitude toward diversity has caused misery for a human being and causing some conflicts. Such conflicts took place in many parts of the world ranging from the west to the east, and from the north to the south. To mention some names of country, ethnic conflict broke out in Serbia, Zaire, Rwanda, Sudan, Russia, Sri Lanka, India and even Indonesia. Having an ill feeling in difference of race, culture, ethnic group, faith and religion triggered such conflicts. Any country or state having such heterogeneous and plural society is vulnerable to be suffered by such conflicts, including Indonesia.

Indonesia is a big country and one of the most populous countries in the world. Based on the national census of 2010 its population reached the number of 237.64 million (BPS 2012). However, according to recent estimates (from various institu- 
tions), Indonesia is estimated to have more than 260 million inhabitants in 2017 ("Population of Indonesia - Demographic Composition" 2017). It becomes the big four in the world in terms of a number of citizens.

Regarding religion, Islam is the religion adhered by the majority of people in Indonesia, followed by Christianity, Hinduism, and Buddhism. Approximately 207.2 million individuals (87.2 percent) of the total population of Indonesia are Muslims. Meanwhile, 16.5 million (6.9 percent of the population) are Protestants, and another 6.9 million individuals (2.9 percent of the population) are Catholics, and 4 million people $(1.7$ percent of the population) are Hindus. In addition to that, there exist small minorities of Buddhists and those who practice Confucianism the most members of which are Chinese community ("Population of Indonesia - Demographic Composition" 2017). From this quantity we just can say that Indonesia is one the biggest countries in the world consisting of diverse and multicultural society.

Being aware that Indonesia consists of plural society it is crucial to have a better understanding of the concept of multiculturalism in order that they can live together side by side in peace and harmony. Thus, introducing the concept of multiculturalism to the citizen is helpful to prevent tensions in society. The best and effective manner to educate people is through multicultural education. Thus, multicultural education can be seen as a response to the diversity of the population.

Basically, multicultural education is an education that respects diversity so that it will not be a source of conflict. The attitude of mutual tolerance is hoped to make the diversity dynamic and enrich the nation's culture. In this multicultural education every civilization and culture is put on the same level and equal. There is no culture that is deemed superior to the other; 
dialog must be taken by every involved party as a mean to solve every problem or tension that may occur among the citizens.

It is the fact that now we live in a multicultural society which consists of members who have various different norms, customs, and tradition as well as beliefs or religions. Living in a multicultural society like Indonesia we have to have an attitude of being tolerant of others of different faiths or beliefs. The best way to transmit the practice of tolerance is through the field of education. In fact, Islamic religious education can also be utilized as a means to transform these values. The main actor in education is a teacher because the teacher can mold the mind of his or her students to become either radical or tolerant people. That is why what we need today is teachers of religious education who have a comprehensive understanding on the subject of religion (Islam), having a good character and are willing to promote values of tolerance and respect to others. Such a kind of teacher will not exist in our society except that we prepare them in a serious and gentle manner. To prepare qualified and open-minded teachers of religious education some crucial actions need to be taken.

Methodologically, this is a qualitative undertaking of literary research. In this research, three stages of data processing were discerned: data collection, data analysis, and data presentation. In the first stage, the author collected all materials containing discussions on the subject be they in the forms of books, articles of journals, and or research findings. All available materials were scrutinized to find out relevant data needed to answer the research questions of this study. All these documents were considered equal, depending on their relevancy to the topic. It is aimed at showing the current state or "state of the art" of the science being discussed. This is so to know that the problem under study has not been adequately addressed. The second stage was data analysis. As this study focuses on texts containing 
information on the subject, it employed the technique of content analysis, defined as "the study of recorded human communications, such as books, websites, paintings and laws" (Babbie 2010, 530) to grasp its real meaning. This technique was used for making inferences by identifying specified characteristics of messages systematically and objectively (Holsti 1969). The objective of employing this technique is in order to be able to present generalization thus it can give theoretical contribution. Data analysis was conducted with the goal of exploring any relevant concepts and basic theories and compare them with the problem under investigation. The last stage was data presentation which was carried out gradually every time the author found out relevant data to the research focus. The processed data were put directly into the corresponding parts of the systematized writing. It is so in order that the writing is structured logically and systematically.

This paper revealed the result of concept analysis regarding the position of teacher in a diverse and pluralistic society, focusing on the importance of empowering teacher of religious education in multicultural society, such as Indonesia. In order to get a better understanding on the topic, this study scrutinizes three issues, namely (1) features of multicultural society, (2) exemplary profile of teacher of religious education who fits in with diverse society, and (3) how to empower this kind of teachers in order to carry out their duty effectively and accepted by pluralistic society. Conceptually, the result of this study will enrich theoretical repertoire of the subject and will be a good reference in terms of functioning or empowering teacher of religious education in multicultural society.

\section{Brief Overview on Multiculturalism}

In Indonesia, the issue of multiculturalism is relatively new in academic sphere. At least, it was not until the end of 1998 
when Soeharto's regime felt down, that this issue became a hot topic among the people. Despite its short period, a lot of works have been produced on this topic. A number of intellectuals have paid attention to this notion. The following are some examples of writings concerning the issue of multiculturalism. Muhammad Ansori Ardiansyah wrote a piece of paper entitled "Konsep Pendidikan Multikultural”. Analyzing from a philosophical perspective, Irhandayaningsih (2012) did a good study in her article under the title "Kajian Filosofis terhadap Multikulturalisme Indonesia", and Sopiah (2009) has also given a good contribution through her paper "Pendidikan Multikultural dalam Pendidikan Islam" in which she examines what the Islamic education can do to support this discourse of multicultural education which is now becoming a worldwide movement. Meanwhile, a renowned Indonesian anthropologist, Parsudi Suparlan (2002) provides us with a good guide on this issue. He wrote an article "Mеnuju Masyarakat Indonesia yang Multikultural”.

As indicated by each title of these writings, those scholars focused their discussion on multicultural education in Indonesia. As many may have known Indonesia is a big nation with its diversity. In these studies the respective writers presented the history of the concept of multicultural education and the definition of it, what is meant by it, what prerequisites it demands, what should the teacher and managers of educational institution prepare to have multicultural education implemented so that a better understanding in the student's mind concerning the diversity and tolerance will be gained. Indeed, those works give contribution in bringing a better understanding to both lay people and academicians in Indonesia in terms of multicultural education. This paper will add to the existing studies and contributes to figuring out the subject under discussion. In the following paragraphs, I will present what constitutes multiculturalism and the related topic at length. 


\section{Defining Multiculturalism}

The concept of multiculturalism has increasingly become an interesting topic to discuss. However, many people have different perception and understanding on what the multiculturalism really is. The defining of multiculturalism can be filled with difficulty, because there are several aspects to this ideology, as well as numerous views and perceptions concerning it. However, according to McKenzie, upon investigation, it can be seen that there are four basic aspects to multiculturalism. Those aspects are: (1) Demographic Multiculturalism, (2) Prescriptive Multiculturalism, (3) Holistic Multiculturalism, (4) Political Multiculturalism (McKenzie 1997). Some considered multiculturalism as simply a program giving recognition to ethno-religious group and their cultures (Heath and Demireva 2014, 161). Multiculturalists advocate the right for other cultures to practice their own cultural traditions and "unique" ways of life, and feel that this liberalistic view is a fair and just position to take (McKenzie 1997).

Pertaining to multiculturalism some definitions can be forwarded. UNESCO defines multiculturalism as three separate but interconnected phenomena. Firstly, multiculturalism is defined as "a description of the demographic make-up of modern states". Secondly, multiculturalism is understood as "a set of norms or principles that uphold the right of all individuals to equal access and ability to participate in social, cultural, economic and political life." Finally, multiculturalism is seen as "a government strategy". From this description, it can be inferred that the first designation refers to a situation, the second articulate values and rights related to this situation, and the third talks about the implementation in policy and practical level (Berman and Paradies $2010,7)$. Rosado gives an operational definition of multiculturalism as "a system of beliefs and behaviors that recognizes and respects the presence of all diverse groups in an organization 
or society, acknowledges and values their socio-cultural differences, and encourages and enables their continued contribution within an inclusive cultural context which empowers all within the organization or society" (Rosado 1996, 2).

Multiculturalism can also be understood as the place of diverse cultures within the framework of certain community. The term "multiculturalism" denotes its recognition that cultural diversity in a certain society is a valued gift that enriches community life and relationship (Sebastian 2014, 338). It is worth mentioning here that in multicultural society a cultural relativism does exist. It can be described as the unsound basis for acceptance of others' values. The acceptance is not based on the worth of those values, but on the expression of those values by others. In other words, what is considered relevant is not its source, but the effect of that certain value on society.

Azra explains that multiculturalism is basically a worldview that can be translated into several cultural policies emphasizing on acceptance toward the reality of religion, plurality and multiple cultures that exist in the society. Parekh, as quoted by Azra, states, "A Multicultural society, then is one that includes several cultural communities with their overlapping but nonetheless distinct conception of the world, the system of meaning, values, forms of social organizations, histories, customs and practices" (Azra 2007). Parsudi Suparlan says multiculturalism is an ideology that admits and praise differences on an equal level either individually or culturally (Suparlan 2002). In short, it can be concluded that multiculturalism is recognition of the existence of diversity in culture.

\section{Categorizing Multiculturalism}

Parekh, as quoted by Azra, differentiates multiculturalism into five categories. (1) Isolationist multiculturalism. It refers to a society where multiple cultural groups can live autonomously 
and involved in a just minimal interaction each other. (2) Accommodative multiculturalism. A society with a dominant culture makes accommodations for the minority culture. It provides and formulates the rule and law for the minority group to maintain and develop their culture. On the other hand, the minority group does not oppose the dominant culture. This type of multiculturalism is applied in some European countries. (3) Automatic multiculturalism. The society is pluralistic where cultural groups try to bring equality with dominant culture into reality and insist to autonomous life in a political framework, which can be accepted collectively. The interest of the cultural groups is to defend their way of life having the equal rights with the dominant group. They challenge the dominant group and create a society where all groups can exist equally. (4) Critical and interactive multiculturalism. The society is pluralistic where the cultural groups are not concerned themselves with autonomous culture, but more on forming collective creation which reflect and assert their distinctive perspectives. (5) Cosmopolitan multiculturalism. The society tries to abolish cultural borders at all in order to create a society in which every individual is no more bound with a certain culture, and vice versa, involved in intercultural experimentations and at the same time develop each culture (Azra 2007).

From the elucidation above, it can be inferred that multicultural society can be understood as the society that includes several cultural communities with their overlapping but with a distinct conception of the world, the system of meaning, values, form of social organizations, histories, customs and practices. This is, in short, the characteristic that exists in multicultural society.

Now, let us examine and relate multicultural society in relation with Islamic education, and particularly the teacher of 
religious education. It must be emphasized that Islam does recognize the existence of different people with their commonalities; this is clearly prescribed in the Qur'an. Islam encourages its followers to encounter one another, that is to cultivate coexistence ( $\left.t a^{\prime} \bar{a} r u f\right)$ with other people regardless differences in culture, ethnicity, language, race and belief or religion. Since Islam expects the Muslims to deal with other people of different backgrounds so the aim of Islamic education is to connect with those people on the basis of what they share and differ about. In connection with this it must be made clear that firstly Islamic education is guided by the attainment of virtue and justice. Secondly, Islamic education has to be implemented in a way that can stimulate encounters of human interdependence and coexistence. Thirdly, Islamic education must be practiced in such a way to support awareness or attentiveness that can counteract the threatening dangers of dogmatism, denial of the others, and injustice. In principle, Islamic education must create space for culture and understanding to connect without sacrificing virtue and justice (Waghid and Davids 2014, 125). Thus, the primary aim of Islamic education is to cultivate human coexistence regardless of people's differences. Cultivating human coexistence in Islamic education needs a big effort from the respective teacher, especially that of religious education, in the classroom. This brings us to the discussion on the exemplary teacher of religious education.

\section{Idealizing Teacher of Religious Education}

\section{Concept of Teacher}

In Islamic literature, there are a lot of terms used to refer to the word teacher. The word 'teacher' means someone who has the duty of teaching. In Arabic, there are a number of words containing the meaning of teaching, such as ustadz, mudarris, 
mu'allim, and muaddib (Nata 2006, 61). In some educational literature, the term teacher often represents the term educator. The teacher is someone whose duty is to teach a lesson or to give instructions in a class or school. More specifically, it can be said that teacher is someone working in the field of education and instructions that is responsible for helping pupils getting his or her maturity. According to Tafsir $(2007,75)$, a teacher is an educator who is holding subjects in school. Usman regards teacher as job title or profession that requires special skills as to teach. To be a teacher is not easy, as it requires special conditions, especially as professional teachers who have to master the intricacies of true education and teaching with a variety of other science that needs to be nurtured and developed through specific training and education (Usman 2001, 5).

Meanwhile, Daradjat said that teacher is a professional educator as he or she has implicitly dedicated his or her self to receive and bear the responsibility of educating those children, which originally become their parents' responsibility. When parents send their children to school they have handed over the responsibility of educating those children to a teacher. It is unthinkable that parents deliver their children to any irresponsible teacher or school. That is why not every person can be or is entitled to be called teacher (Daradjat 1993, 39). It should be noted that in the implementation of Islamic religious education the role of the teacher is highly important because it is the teacher who can navigate to whatever direction the education is directed. Now let us turn to discuss what kind of profile of teacher is promoted in Islam.

\section{Profile of Teacher of Religious Education}

It is imperative to note that so far the practice of education in the learning process of religious education in the class, partic- 
ularly in Indonesian context, mostly focused much on cognitive aspect rather than growing awareness of religious values, and it also often ignores affective aspect that is the will to practice values of religious teachings. As a consequence, there is a discrepancy between knowledge and practice of religious values. Thus, (Islamic) religious education fails to shape Islamic personalities in the selves of pupils (Muhaimin 2002, 88). I think this discrepancy must be stopped from continuing, and we can put our hope to do this duty on the hand of teachers of religious education, because at schools it is the teacher who can play this essential role in order to bridge these gaps.

A Muslim teacher has a responsibility to make learning process of religious education at school touches not only cognitive aspect but also affective and psychomotor aspect as well. In this case what is needed is a supreme teacher. In Islamic perspective, such an idealized teacher can be found in an ultimate profile of teacher, as many Muslim scholars have promoted.

Al-Qalqasyandi, a Muslim educator in the era of the Fatimid caliph in Egypt, described the profile of teacher of religious education as follows. Firstly, from the perspective of physical requirements: (a) the teacher must have a great body, (b) the teacher must have a shining face, (c) the teacher must have a wide forehead and clean from hair. Secondly, from the perspective of psychological requirements: (a) the teacher must have a healthy mind, (b) the teacher must have keen understanding, (c) the teacher must have civilized heart, be fair and knight, (d) the teacher must have a broad chest, (e) the teacher must know the meaning of what he or she talks about, (f) the teacher must have a clear statement and easily understood, (f) the teacher must choose glorious words, (g) the teacher must avoid something leading to words that are not clear (Zuhairini 1995, 169-70). 
Meanwhile, Muhammad Athiyyah al-Abrasy, another prominent Muslim scholar, states that a Muslim teacher must have seven characters. (1) A teacher must have ascetic nature that is not prioritizing getting materials in performing his or her duty except hoping the sincere from God. This does not mean that a teacher cannot receive materials reward, because he or she is still a human being who is in need of money to support his or her life. (2) A teacher must have a clean soul and good morals and avoid the disgraceful nature. (3) A teacher must be sincere in performing his or her duty, and always sincere to add knowledge to his or her pupils for the sake of their success. (4) A teacher must be forgiven for his or her pupils, he should be able to refrain from anger, and should have a lot of patience and compassion to his or her pupils. (5) A teacher must put himself or herself as father or mother for his or her pupils, in other words, a teacher must love his or her pupils as his or her own children. (6) A teacher must know the talent, temperament and character of his or her pupils, this is meant that a teacher will not be wrong in comprehending his or her pupils, and make it easy for the teacher determining learning strategy according to the level of intelligence of his or her pupils. (7) A teacher must master the subject matter he or she is teaching and must develop his or her knowledge continuously (Nata 2006, 72-76).

In addition, in the context of teaching and learning process in the atmosphere of multicultural society teachers should learn their students' identity and backgrounds to become more culturally competent (Aronson, Amatullah, and Laughter 2016, 145). In other words, the teacher may not become ignorant about their students' religious beliefs, because being ignorant in that matter will result in insensitivity, inequity and marginalization (Allgood 2016, 274). Therefore, in order to perform their duty at maximum level teachers must be aware to enhance academic 
skill and concepts and to engage in critical reflection as well as to upgrade their competence.

Basically, the profile above reveals the personal and professional aspect of a teacher. Personal aspect concerns about personality of the teacher itself put in the main position and is hoped to shine in a social dimension in the relationship between teacher and its pupils, its colleagues, and community. Meanwhile, professional aspect concerns the role of the profession as a teacher in the sense of having professional qualification as a teacher.

Put in Indonesian context, professional aspect of teacher can be traced in the law of Republic of Indonesia No. 14 year 2005 stating that: "A teacher is professional educator with the main task of educating, teaching, guiding, directing, training, assessing and evaluating leaners in early childhood education in the formal education, basic education and middle education" (Nuansa Aulia's Editor 2006). Furthermore, concerning the professionalism, which must be held by every teacher, the Law outlines the principles of professionalism as follows. (1) Having talent, enthusiasm, spirit call and idealism. (2) Having a commitment to improving the quality of education, faith, piety and good character. (3) Having academic qualifications and educational background according to the field of duty. (4) Having the necessary competence in accordance with the task. (5) Having the responsibility for the execution of tasks professionalism. (6) Earning income determined in accordance with work performance. (7) Having the opportunity to develop in a sustainable manner with the professionalism of lifelong learning. (8) Having legal protection in carrying out the task of professionalism. (9) Having a professional organization that has the authority to regulate matters relating to the duties of professionalism of teachers (Nuansa Aulia's Editor 2006, 20-21). 
These are qualities that should be possessed by the professional teacher. It is worth noting that in performing their duties professional teachers should also have competence in their students' cultures, as it is assumed that teachers who are culturally competent have a better awareness of their cultural, ethnic, and gender attitudes, expectations, learning preferences, teaching style, and personal biases (Bilal and Rizvi 2016, 238). It should be added that every professional teacher has an obligation to defend their students' religious identities and sensibilities in the same way that they would protect their racial, ethnic, and linguistic identities (Allgood 2016, 278). That is the main function of the teacher in the classroom.

A teacher is required for a commitment to professionalism in carrying out his or her duties. One is said to be a professional when there is an inherent nature of highly dedicative on his or her job, an attitude of commitment to quality and process and the work, as well as the attitude of continuous improvement, which is always trying to improve and update the models or the way of working in accordance with the guidance of his time on an ongoing basis, which based on the sharp awareness that the task of educating is the task of preparing the next generation who will live in his time in the future (Muhaimin 2006, 7-8). This profile of idealized teacher can be made as a role model. When a teacher accomplish his or her duty of giving instruction at school he or she must understand the nature of our society, which is not homogenous, but diverse and pluralistic. This brings us to the discussion on how to empower teachers of religious education who are capable of performing their job successfully in multicultural society.

\section{Empowering Teacher of Religious Education}

\section{Need for a Multicultural Education}

Nowadays, despite its major educational reform teacher ed- 
ucation is still unable to address the issues of multiculturalism and multicultural needs of future teachers. Even in America, one of the biggest multicultural countries, pre-service teachers have been said as not being prepared to deal with the challenges of multicultural/ cross-cultural education. The consequence of it is pre-service teachers in that country felt inadequate to deal with either cognitive or affective aspect of multicultural education (Barry and Lechner 1995, 150). Therefore, a multicultural education is needed for teachers in order to teach students coming from different background either the level of socio-economic, cultural heritage or religious affiliation. The advantage gained is that teachers who are culturally competent will show a better awareness of their cultural, ethnic, gender attitudes, teaching style as well as personal biases. However, it must be admitted that to develop cultural competency is quite hard since it requires several conditions and also needs time (Bilal and Rizvi 2016, 237-38). In spite of being hard, some actions need to be taken in order to materialize that goal, particularly in the Indonesian context.

Talking about a concept of multicultural education, James Bank (2007, 83-94) explains that values in multicultural education have to be promulgated in the instructional process, which has several dimensions. The dimensions are: (1) Content integration, which means that all material being taught to students in the class should be integrated with views of other religious groups, to enlarge the student's insight with perspective of others. (2) Knowledge construction, which means students are involved in the process of attaining knowledge with critical thinking. (3) Prejudice reduction, which means students are trained to reduce prejudice to others, and to develop their attitude in line with values of democracy. (4) Equity pedagogy, which means students are taught that human beings are equal and any form of discrimination is not allowed to be practiced. 


\section{Developing Multicultural Awareness in School}

In order to be able to cope with the diversity in our society, it is imperative to make teachers of religious education aware of what is going on. Steps that must be taken by teachers of religious education in developing multicultural awareness in the school include the following points. First of all teachers of religious education must understand the trends that have emerged in this era of unlimited technology and communication, which is not only a challenge for teachers of religion but also for religious communities at large. Those trends are (1) internal diversity, (2) structural diversity, (3) cultural pluralism, (4) scientific criticism, that is a criticism of science against religious explanations that are still traditional (Muhaimin 2002, 35). Thus, even inside circles itself a different understanding of certain matters does exist. Teachers of religious education should take this into their consideration.

The tendency of internal diversity, structural diversity and cultural pluralism affirmed the need for learning efforts of (Islamic) religious education capable of forming personal piety and social piety on students. The task of a teacher of religious education is not only to transfer religious knowledge to learners but also to maintain religious education in order not to foster the spirit of fanaticism, because cultivating an attitude of intolerance among the public and students will only weaken religious life harmony and national unity. For Indonesian context, the pluralistic society, whether in religion, ethnicity, race, tradition, culture and so on, are vulnerable to the emergence of disagreements and social conflicts. Therefore, religion in public life can act as a unifying factor and, on the contrary, can act as a breaker factor as well. Pluralistic society requires a bond of civility, the association between each other are bound together in a 'civility'. This tie can actually be built on the values of universal religion. 
Therefore, teachers of religious education are required to be able to teach subject matters that function as a moral guide in the life of the pluralistic or multicultural society. In addition, teachers of religious education is also tested for their ability to elevate the dimensions of conceptual and substantial religious teachings, such as honesty, fairness, solidarity, awareness of their rights and obligations, sincerity in giving and so on, to be realized with the life of a pluralistic society mentioned (Yaqin 2005, 56).

Unfortunately, however, a paradigm in religious understanding adopted by our society is still relatively exclusive. This understanding cannot be underestimated because, in addition to being one of the causes of conflict, this understanding can form a personal antipathy toward people of other religions and close space for dialogue with other religions. Such a condition will raise personal feel that his or her religion is the truest one and other streams are wrong and even heretical which in turn will bring an attitude of destroying and damaging other religions or sects (Yaqin 2005, 56).

It must be admitted that in Islamic education many teachers are still applying the conventional method and utilize indoctrination approach, which tends to deny the reality of plurality. It is hard to determine what number their percentage is but the fact is that they do exist. In turn, this approach will produce totalistic perspective of social and moral philosophy, which is quite dangerous when delivering Islamic teachings to their students. This approach must be corrected, and education of anti-radicalism needs to be brought and implemented in Islamic education curriculum (Maarif 2017, 56). In addition to that when delivering a lesson in the class, teachers of religious education should be able to establish the relevance of Islamic teachings to each area of modern knowledge (Muslih 2009, 23). This is one of the 
efforts to understand Islamic religious teachings with an open mind while absorbing perspective of others or outsiders.

To prevent religious understanding of this exclusive society from continuing to grow it is necessary to take some precautionary measures. Measures to be undertaken are, among others, the construction of a more inclusive understanding of religious plurality, understanding of multicultural society, undertaking persuasive-dialogues, carrying out society development through education, mass media and social interaction (Yaqin 2005, 56).

\section{Promulgating Inclusive Understanding of Religiosity}

One of the channels to construct a more inclusive understanding of religion, I believe, is through empowering teachers at schools in delivering the subject of religious education to their students. To materialize this goal teacher of religious education must be upgraded in terms of awareness and understanding of being part of multicultural society that is diverse in nature. Furthermore, they must be empowered in terms of knowledge and skill in delivering the subject of religious education to their students in school.

Preparing students to be mature and to be a good member of multicultural society is a great task of teachers of religious education. In order to be able to arrive this ideal teacher of religious education should teach and internalize in the mind of the student's certain paradigms of religious understanding to make the students tolerant and respect to other people of different cultures and religions. The following are among the paradigms that teachers of religious education should promote to their students.

The first is plural and inclusive paradigm of religiosity. This means that it can receive opinions and understanding of other religions that have a base of divinity and humanity. Understanding cultural diversity means accepting the diversity of cultural 
expressions containing values of humanity. While the humanist understanding is to recognize the importance of human values in religion, which means someone who is religious should be able to implement the values of humanity, respect the rights of others, care for others and try to build peace for all mankind. The second is a persuasive-dialogue paradigm, which means forwarding more dialogue and peaceful ways to see the disputes and differences of religious understanding rather than doing physical measures such as terrorism, war, and other forms of violence. The third is a contextual paradigm, which means applying critical thinking in understanding religious texts that cannot be contested. However, some of the religious texts still require critical interpretation in efforts to address current religious problems. The fourth is a substantive paradigm, which applies religious values rather than just looks and glorifies religious symbols. Last but not least is the paradigm of active understanding of the social, which means that religion is not a means of fulfilling the needs of personal spirituality only, but the more important one is to build unity and solidarity for all of humanity through real social actions that can improve the welfare of mankind (Yaqin 2005, 57).

By establishing a paradigm in understanding religious teachings, which is more humanist, pluralist, and contextual it is expected that universal values that exist in a religion such as truth, justice, humanity, peace, and welfare of mankind can be enforced in order to stimulate the harmony and peace among religions. The orientation of education should not refer only to the formation of the religious understanding of texts and rituals, but also refers to the contextual and social understanding. The curriculum is expected not only aims at building the capacity of students to religious subjects but also to build a sense of students who are religious and caring (Yaqin 2005, 57). 
Therefore, teachers of religious education should always pay attention to the following issues in order to establish an effective Islamic education system. Firstly, teachers should teach their students how to respect the lives of others. Secondly, teachers should give their students the opportunity to get them involved in the deliberations - a process where students can speak their minds. Thirdly, teachers should teach their students about their rights for the protection of life, liberty, and property, the right to freedom of conscience and the right of association (Waghid 2013, 330).

It should be emphasized here once again, that teacher is an important factor in the implementation of religious values of inclusive and moderate understanding in schools. Teachers have a significant role in religious education based on multicultural society. If a teacher has a religious understanding paradigm that is inclusive and moderate, then he or she will also be able to teach and implement these values of religiosity to the students in the school.

For this reason, teachers of religious education should always promulgate and cultivate certain basic character into the mind and soul of their students. These characters, among others are, respect and responsibility, honesty, fairness, tolerance, wisdom, discipline, helpfulness, compassion, cooperation, courage, and a set of democratic values. Certainly, the teachers of religious education should teach those characters under an Islamic education system once the model of Islamic education is developed on democratic, participatory, and humanist spheres. It is believed that in this model of Islamic education student will learn a lot, and in turn, they can provide themselves with skills such as mutual respect, freedom of speech and expression as well as being able to live together with other people having different perspectives (Maarif 2017, 54). 
Teachers of religious education must be empowered to continue developing awareness of multiculturalism to their students. The multiculturalist attitude in life is not getting people to religion by way of syncretism, interpreting that all religions are the same or trying to mix blend of all religions into one. Nor asking someone to do a synthesis of religion or creating a new religion but what is meant by the multiculturalist attitude is the attitude that agrees with his or her differences (agree in disagreement). He or she is convinced that the religion that he or she embraces is the most correct and good; nevertheless, among religions, there are differences and also similarities (Muhaimin 2002, 140).

Thus, something that teachers of religious education should promote is the attitude of tolerance and respect to others. This is an important attitude as religious intolerance can damage students' interpersonal relationships. Education is believed to be able to play a significant role in public life both in political and cultural aspects. So that it is one of the best media for preparing and shaping social life and takes a central position in transforming values and idealism into practice (Nuryatno 2008, 81).

In the context of diverse society, religious education can be utilized as a means of promoting an attitude of tolerance, as King said that, "Religious Education has always been seen as a subject which contributes positively to both multi-cultural and intercultural studies" (King 2010, 284). In Indonesian context, it is really suitable to use (Islamic) religious education for promoting the values of tolerance in multicultural society.

Due to this central position, (Islamic) religious education can be utilized in the best way to promote good values of Islamic teachings to all students for the benefit of not only Muslims but also for the whole humankind in the universe. As the teachers become the main actor in the educational sphere, they 
bear responsibility to promote the values and Islamic teachings that benefit to all. In order to establish pupils or students who are able to live together in a multicultural society, the teachers of religious education in the classroom should promote values such as tolerance and respecting others of different faiths. Thus, in this context, empowering teachers of religious education in promoting values and teachings of Islam as a blessing for the entire universe (rahmatan lil 'alamin) in order to be fit with the nature of multicultural society where we are living now is a must and therefore recommended.

\section{Conclusion}

In the discussion above I have argued the importance of making the teacher of religious education aware of what is going on in our society, and of upgrading and empowering the teachers and drive them to internalize certain paradigms of religious understanding in the mind of the students in order to be fit in with the nature of multicultural society. Afterwards, conclusions can be drawn in several points as follows.

Firstly, multicultural society can be understood as a society which consists of several cultural communities with their overlapping but distinct conception of the world, system of meaning, values, forms of social organizations, histories, customs and practices. In other words, multiculturalism can be described as an ideology that admits and praise differences on an equal level either individually or culturally.

Secondly, the idealized profile of teacher of religious education is a type of teacher who meets certain qualifications prescribed by Islamic teachings and Islamic heritage, and in Indonesian context, also as guided by the law and regulation in Indonesia. The qualified teachers of religious education who fit in for performing their job in multicultural society like Indone- 
sia are those who have certain characteristic compatible with the nature of that society, such as, among others, having sense of tolerance and respect to the faiths or beliefs of others.

Thirdly, teachers of religious education play a significant role in forming students' character as the teachers can navigate their students to a certain direction. Therefore, these teachers should be made aware of their task, namely producing students possessing good characters and prepare them to be good members of society which is diverse in nature. For this purpose, firstly teachers of religious education must be upgraded in terms of awareness of being part of multicultural society. Afterwards, they must be empowered in terms of knowledge and skill in delivering the subject to their students in school. In preparing their students to be good members of multicultural society, teachers of religious education should adopt certain paradigms of religious understanding to make them tolerant and respect other people having different cultures and religions. In addition, the teachers should develop and promulgate an inclusive understanding of religiosity to their students. The goal to be achieved is to form personal pity as well as social pity on students to strengthen harmony and national unity. In short, teachers of religious education bear the responsibility to promote the values and Islamic teachings that benefit to all, as Islam is a blessing for the entire universe.

\section{Bibliography}

Allgood, Ilene. 2016. "Faith and Freedom of Religion in U.S. Public Schools: Issues and Challenges Facing Teachers." Religious Education 111 (3). Routledge: 270-87. doi:10.1 080/00344087.2016.1169882.

Aronson, Brittany, Tasneem Amatullah, and Judson Laughter. 2016. "Culturally Relevant Education: Extending the Conversation to Religious Diversity." Multicultural Perspec- 
tives 18 (3). Routledge: 140-49. doi:10.1080/15210960. 2016.1185609 .

Azra, Azyumardi. 2007. Identitas Dan Krisis Budaya, Membangun Multikulturalisme Indonesia. Jakarta: Pustaka Indonesia.

Babbie, Earl R. 2010. The Practice of Social Research. Wadsworth: Cengage Learning.

Baidhawy, Zakiyuddin. 2005. Pendidikan Agama Berwawasan Multikultural. Jakarta: PT. Gelora Aksa Pratama.

Banks, James A. 2007. Educating Citizens in a Multicultural Society. New York and London: Teachers College Press.

Barry, Nancy H., and Judith V. Lechner. 1995. "Preservice Teachers' Attitudes about and Awareness of Multicultural Teaching and Learning." Teaching and Teacher Education 11 (2). Pergamon: 149-61. doi:10.1016/0742-051X(94)00018-2.

Berman, Gabrielle, and Yin Paradies. 2010. "Racism, Disadvantage and Multiculturalism: Towards Effective Anti-Racist Praxis." Ethnic and Racial Studies 33 (2). Taylor \& Francis Group: 214-32. doi:10.1080/01419870802302272.

Bilal, Muhammad, and Syed Asad Abbas Rizvi. 2016. "Multicultural Teacher Preparation in Practice: A Hermeneutical Disposition.” European Scientific Journal 12 (31): 18577881. doi:10.19044/esj.2016.v12n31p233.

BPS. 2012. "Penduduk Indonesia Menurut Provinsi 1971, 1980, 1990, 1995, 2000 Dan 2010.” Badan Pusat Statistik. https://www.bps.go.id/linkTabelStatis/view/id/1267.

Daradjat, Zakiah. et al. 1993. Ilmu Pendidikan Islam. Jakarta: Bumi Aksara. 
Heath, Anthony, and Neli Demireva. 2014. "Has Multiculturalism Failed in Britain?" Ethnic and Racial Studies 37 (1). Routledge: 161-80. doi:10.1080/01419870.2013.808754.

Hilmy, Masdar. 2003. “Menggagas Paradigma Pendidikan Berbasis Multikulturalisme.” Jurnal Ulumuna 7 (2).

Holsti, Ole R. 1969. Content Analysis for the Social Sciences and Humanities. Reading, MA: Addison-Wesley.

Irhandayaningsih, Ana. 2012. "Kajian Filosofis Terhadap Multikulturalisme Indonesia." HUMANIKA 15 (9). doi:10.14710/humanika.15.9.

King, Carolyn. 2010. "Faith Schools in Pluralistic Britain: Debate, Discussion, and Considerations." Journal of Contemporary Religion 25 (2). Routledge: 281-99. doi:10.1080/13537901003750977.

Maarif, Syamsul. 2017. "Islamic Education in an Open Society: Cultivating Social Coexistence." MAGNT Research Report 4 (2): 50-61.

McKenzie, Cameron. 1997. "The Menace of Multiculturalism.” Australian Daily Issue. http://www.gwb.com.au/gwb/ news/pc/multi3.htm.

Muhaimin. 2002. Paradigma Pendidikan Islam: Upaya Mengefektifkan Pendidikan Agama Islam Di Sekolah. Bandung: Rosda Karya.

- 2006. Nuansa Baru Pendidikan Islam: Mengurai Benang Kusut Dunia Pendidikan. Jakarta: Raja Grafindo.

Muslih. 2009. Islamization of Knowledge and Islamic Educational Reform: Understanding Al-Faruqi's Thought. Yogyakarta: IDEA Press. 
Nata, Abuddin. 2006. Filsafat Pendidikan Islam I. Jakarta: Logos Wacana Ilmu.

Nuansa Aulia's Editor. 2006. Himpunan Perundang-Undangan Republik Indonesia Tentang Guru Dan Dosen. Bandung: Nuansa Aulia.

Nuryatno, M. Agus. 2008. Mazhab Pendidikan Kritis Menyikap Relasi Pengetahuan, Politik, Dan Kekuasaan. Yogyakarta: Rasist Book.

"Population of Indonesia - Demographic Composition.” 2017. Indonesia-Investment. https://www.indonesia-investments.com/culture/population/item67.

Rosado, Caleb. 1996. "Toward a Definition of Multiculturalism."

Sebastian, J. Jayakiran. 2014. "Engaging Multiculturalism as Public Theologians." International Journal of Public Theology 8 (3). Brill: 335-43. doi:10.1163/1569732012341355 .

Sopiah. 2009. "Pendidikan Multikultural Dalam Pendidikan Islam.” Forum Tarbiyah 7 (2): 157-66.

Suparlan, Parsudi. 2002. "Menuju Masyarakat Indonesia Yang Multikultural.” Bali.

Tafsir, Ahmad. 2007. Ilmu Pendidikan Dalam Perspektif Islam. Bandung: PT Remaja Rosdakarya.

Usman, Moh. Uzer. 2001. Menjadi Guru Profesional. Bandung: PT Remaja Rosdakarya.

Waghid, Yusef. 2013. "Islamic Education and Cosmopolitanism: A Philosophical Interlude." Studies in Philosophy and Education 33 (3): 329-42. doi:10.1007/s11217-013-9390-3. 
EMPOWERING TEACHER OF RELIGIOUS EDUCATION

Waghid, Yusef, and Nuraan Davids. 2014. "Muslim Education and Its (In)commensurability with Multiculturalism: Some Thoughts on the Imaginative Madrassah.” Policy Futures in Education 12 (1). SAGE PublicationsSage UK: London, England: 124-30. doi:10.2304/pfie.2014.12.1.124.

Yaqin, M. Ainul. 2005. Pendidikan Multikultural: Cross Cultural Understanding Untuk Demokrasi Dan Keadilan. Yogyakarta: Pilar Media.

Zuhairini. 1995. Filsafat Pendidikan Islam. Jakarta: Bumi Aksara. 
This page intentionally left blank 